\title{
Adulteration and microbiological profile of the collected industrial raw milk from rural area of Rangpur district of Bangladesh
}

\begin{abstract}
This study was aimed to reveal the quality test of raw milk in quality control laboratory of a well reputed dairy industry in Bangladesh. Raw milk of cow that was collected from various dairy farms located in rural areas of Rangpur district of Bangladesh. Then platform test was accomplished. Platform test included Organoleptic test, Formalin test, Sugar test, Soda test, Lacto test etc. After platform test of raw milk, good quality milk was then allowed to microbiological tests. This study will help to know the common practice of adulterant in raw milk and microbial profile of industrial raw milk collected from rural area of Bangladesh.
\end{abstract}

Keywords: platform test, preservatives, microbial test, total viable bacterial count, total coliform count
Volume 3 Issue 4 - 2016

\author{
Abdullah AI Mamun,' Samun Sarker, ${ }^{2}$ Hasan \\ Abdullah ${ }^{3}$ \\ 'Chittagong Veterinary and Animal Sciences University, \\ Bangladesh \\ ${ }^{2}$ Department of Microbiology and Veterinary Public Health, \\ University of Chittagong Veterinary and Animal Sciences, \\ Bangladesh \\ ${ }^{3}$ University of Chittagong Veterinary and Animal Sciences, \\ Bangladesh
}

Correspondence: Abdullah Al Mamun, Faculty of Food Science \& Technology, Chittagong Veterinary \& Animal Sciences University (CVASU), Khulshi-4225, Chittagong, Bangladesh, Tel 880179832 7525,Email aamfst@gmail.com

Received: November 29, 2015 | Published: June 22, 2016
Abbreviations: CFU, colony forming units; ETC, etcetera; F, fat; ML, milliliter; TCC, total coliform count; TVBC, total viable bacterial count

\section{Introduction}

Milk may be defined as the whole, fresh, clean, lacteal secretion obtained by the complete milking of one or more healthy milk animals, excluding that obtained within 15 days before or 5 days after calving or such periods as may be necessary to render the milk practically colostrums-free and containing the minimum prescribed percentage of milk fat and milk-solids-not-fat. ${ }^{1}$ Milk is an essential part of daily diet for the growing children and expectant mothers. ${ }^{2}$ Milk, is a major constituent of the diet, its quality assurance is considered essential to the welfare of a community. ${ }^{3}$ Consumers always demands nutritionally enriched milk and dairy products. ${ }^{4,5}$

The nature of adulterants generally encountered in milk and milk products are water, removal of fat, addition of skim milk powder, reconstituted milk, thickening agents such as starch, flour, glucose, urea, salt, chlorine. ${ }^{6}$ Preservatives such as neutralizers which usually consists of sodium bicarbonate, sodium carbonate, sodium hydroxide and calcium hydroxide. Some rarities include animal fats, aflatoxins and vegetable oils. ${ }^{?}$

Bacterial contamination of raw milk from water, soil, vegetation, and bedding material, vary in the numbers and types of organisms that can be introduced into raw milk. ${ }^{8}$ Contamination with psychrotrophic microflora has been associated with bedding material, untreated water, soil, and vegetation; coliform contamination with soil; and spore formers with bedding material. ${ }^{9}$

Measurement of bacterial numbers in milk is of interest because they are indicator of poor milk hygiene production of milk. ${ }^{10}$ Some microbes such as gram negative Psychrotrophs, Coliforms and other pathogenic bacteria such as Escherichia Coli, Staphylococcus aureus may also be found in milk. ${ }^{11}$ This study help to know what types of adulterants are used to increase volume or concentration. Common preservatives added to prolong shelf life. And microbial profile of raw milk, which is related to hygiene practice, disease of cattle and environment.

\section{Materials and methods}

\section{Adulteration and preservatives}

Presence of the formalin, rosalic acid, sucrose, starch and salt was tested by specific qualitative tests (www.dairyforall.com)

Rosalic acid test (Soda test): Take $5 \mathrm{ml}$ of milk in a test tube and add $5 \mathrm{ml}$ alcohol followed by 4-5 drops of rosalic acid. If the colour of milk changes to pinkish red, then it is inferred that the milk is adulterated with sodium carbonate/sodium bicarbonate and hence unfit for human consumption.

Formalin test: $10 \mathrm{ml}$ of milk was taken in test tube and $5 \mathrm{ml}$ of conc. sulphuric acid was added on the sides of the test tube without shaking. Appearance of a violet or blue ring at the intersection of the two layers indicated the presence of formalin.

Sucrose test: $10 \mathrm{ml}$ of milk was taken in a test tube and $5 \mathrm{ml}$ of hydrochloric acid was added along with $0.1 \mathrm{~g}$ of resorcinol. Then the test tube was shaken well and placed in a boiling water bath for $5 \mathrm{~min}$. Appearance of red colour indicated the presence of added sugar in milk.

Starch test: $3 \mathrm{ml}$ milk was taken in a test tube and boiled thoroughly. Then milk was cooled to room temperature and added with 2 to 3 drops of $1 \%$ iodine solution. Change of colour to blue indicated that the milk was adulterated with starch. 
Salt Test: $5 \mathrm{ml}$ of silver nitrate $(0.8 \%)$ was taken in a test tube and added with 2 to 3 drops of $1 \%$ potassium dichromate and $1 \mathrm{ml}$ of milk and thoroughly mixed. If the contents of the test tube turned yellow in colour, then milk contained salt in it. If it was chocolate colored, then the milk was free from salt

The lactometer test: Lactometer reading was tested by specific quantitative test (www.fao.org). Mix the milk sample gently and pour it gently into a measuring cylinder (300-500). Let the Lactometer sink slowly into the milk. Read and record the last Lactometer degree $\left({ }^{\circ} \mathrm{L}\right)$ just above the surface of the milk. If the temperature of the milk is different from the calibration temperature (Calibration temperature may be $20^{\circ} \mathrm{C}$ ) of the lactometer, calculate the temperature correction. For each ${ }^{\circ} \mathrm{C}$ (Degree Celsius) above the calibration temperature add $0.2^{\circ} \mathrm{L}$; for each ${ }^{\circ} \mathrm{C}$ below calibration temperature subtract $0.2^{\circ} \mathrm{L}$ from the recorded lactometer reading.

\section{Microbial tests of raw milk}

The plate count method relies on bacteria growing a colony on a nutrient medium so that the colony becomes visible to the naked eye and the number of colonies on a plate can be counted. To be effective, the dilution of the original sample must be arranged so that on average between 30 and 300 colonies of the target bacterium is grown. The laboratory procedure involves making serial dilutions of the sample $(1: 10,1: 100,1: 1000$, etc.) in sterile water and cultivating these on nutrient agar in a dish that is sealed and incubated. Total plate count measured as $\mathrm{cfu} / \mathrm{ml}$. All of the tests were performed according to the standard methods for the examination of dairy products according to
American Association of Public Health. ${ }^{12}$

\section{Results and discussion}

Test results adulteration and preservatives of raw milk is given in Tables $1 \& 2$ and microbiological test results of raw milk are given in Table 3.

Table 1 shows the result of 25 raw milk samples lacto tests. This result shows that low lactometer reading which indicates addition of water. All samples are collected from different points of Rangpur but most of them adulterated by adding water. By adding water it increases total volume and minimize developed acidity for prolonged shelf life.

Table 2 shows result of 25 raw milk samples for various adulterant and preservatives. During study all of 25 samples were free from formalin. Presence of sugar in 8 samples from 25 , i.e. $32 \%$ samples was adulterated by sugar which helps to improve taste of diluted raw milk. $8 \%$ samples were detected with Soda and $4 \%$ were detected with starch. All samples were free from salt adulteration. It is clear from above result that, raw milk samples from Baldipukur and Mithapukur was most adulterated.

Table 3 show the result of total viable bacterial count (TVBC) and total coliform count (TCC). This study revealed that total viable bacterial count is much higher and it may be cause of unhygienic condition, environmental factor or disease of cattle. Coliform bacteria were detected in the raw milk. Presence of coliform bacteria indicates that milk was contaminated with fecal and environmental bacteria. ${ }^{13}$

Table I Average of lactometer reading test $(\mathrm{N}=25)$

\begin{tabular}{lllllll}
\hline Parameters & Satmatha & Mithapukur & Ranipukur & Baldipukur & Badarganj & Average \\
\hline Lacto Test & 29 & 30 & 29 & 29 & 29 & 29.2 \\
\hline
\end{tabular}

Table 2 Presence of adulterant and preservative in the raw milk samples collected from various point of Rangpur districts

\begin{tabular}{|c|c|c|c|c|c|c|c|c|c|c|c|c|}
\hline \multirow{2}{*}{ Parameters } & \multicolumn{2}{|c|}{ Satmatha } & \multicolumn{2}{|c|}{ Mithapukur } & \multicolumn{2}{|c|}{ Ranipukur } & \multicolumn{2}{|c|}{ Baldipukur } & \multicolumn{2}{|c|}{ Badarganj } & \multicolumn{2}{|l|}{ Total } \\
\hline & $+(v e)$ & $-(\mathrm{ve})$ & $+(v e)$ & $-(\mathrm{ve})$ & $+(v e)$ & $-(v e)$ & $+(v e)$ & $-(v e)$ & $+(v e)$ & $-(v e)$ & $+(v e)$ & $-(\mathrm{ve})$ \\
\hline Formalin Test & 0 & 5 & 0 & 5 & 0 & 5 & 0 & 5 & 0 & 5 & 0 & 25 \\
\hline Sugar & 2 & 3 & I & 4 & 1 & 4 & 3 & 2 & I & 4 & 8 & 17 \\
\hline Soda Test & 0 & 5 & I & 4 & 0 & 5 & I & 4 & 0 & 5 & 2 & 23 \\
\hline Starch & 0 & 5 & 1 & 4 & 0 & 5 & 0 & 5 & 0 & 5 & I & 24 \\
\hline Salt & 0 & 5 & 0 & 5 & 0 & 5 & 0 & 5 & 0 & 5 & 0 & 25 \\
\hline Total & 2 & 23 & 3 & 22 & I & 24 & 4 & 21 & I & 24 & - & - \\
\hline
\end{tabular}

Table 3 Average of total viable bacterial count and total coliform count of raw milk $(\mathrm{N}=25)$

\begin{tabular}{lll}
\hline Sample & TVBC(cfu/ml) & TCC(cfu/ml) \\
\hline Satmatha & $4.69 \times 10^{6}$ & $2.09 \times 10^{5}$ \\
Mithapukur & $6.10 \times 10^{6}$ & $2.1 \times 10^{5}$ \\
Ranipukur & $5.12 \times 10^{6}$ & $1.92 \times 10^{5}$ \\
Baldipukur & $6.25 \times 10^{6}$ & $3.25 \times 10^{5}$ \\
Badarganj & $4.97 \times 10^{6}$ & $1.97 \times 10^{5}$ \\
\hline
\end{tabular}




\section{Conclusion}

It may conclude that people added various adulterants to increase milk volume to earn more profit. Water is most common adulterant used to increase volume. Sugar and starch also used as adulterant to minimize change due to added water. Sugar also gives taste of diluted milk. Preservatives are used to prolong shelf life. The trends of adding adulterant and preservatives are high in milk samples from Baldipukur and Mithapukur area. Microbiological tests indicated that hygiene practice is very low in milk production level of these areas. These findings may be helpful for the concerned regulatory bodies to monitor the quality of the milk in the market. Dairy farmers should be taken as the target group of awareness creation for safety measure of public health. It would be a great interest if further investigations are to be carried out to examine quality components of milk. The study will create awareness among consumers level. ${ }^{14}$

\section{Acknowledgements}

None.

\section{Conflict of interest}

Author declares that there is no conflict of interest.

\section{References}

1. Sukumar D. Outlines of Dairy Technology. New Delhi: Oxford University Press; 1991. 2p.

2. Awan JA, Rehman US. Elements food and nutrition. Faisalabad: NuiTech Communications; 2005.

3. Torkar KG, Teger SG. The Microbiological quality of raw milk after introducting the two day's milk collecting system. Acta Agri Slovenica. 2008;92(1):61-74.
4. Bangladesh Standard of Dairy product, BDS - 1985. Bangladesh Standard Testing Institutions, Bangladesh.

5. Boume MC. Food texture and viscosity, concept and measurement. New York: Academic Press Inc; 1982:1-23 p.

6. Chanda T, Debnath GK, Hossain ME, et al. Adulteration of raw milk in the rural areas of Barisal district of Bangladesh, Bangladesh Animal Husbandry Association. Bangladesh Journal of Animal Science. 2012;41(2):112-115

7. Monika G, Gupta MP. Recent Trends in detection of adulteration of milk \& dairy products. 8th ed. Varanasi: Dairy Book; 2008:43-52 p.

8. Hossain TJ, Alam MK, Sikdar D. Chemical and Microbiological Quality Assessment of Raw and Processed Market Milk of Bangladesh. Continental J Food Science and Technology. 2011;5(2):6-17.

9. Marth EH, Steele JL. Applied Dairy Microbiology. 2nd ed. Madison Avenue, New York: Marcel Dekker, Inc; 2011:59-63 p.

10. Chanda GC, Uddin GMN, Aparna D, et al. Microbiological Profile of the Traditionally Collected Industrial Raw Milk from the Milk Pocket Zones of Bangladesh. Bangladesh J Microbiol. 2008;25(1):17-20.

11. Tatini SR, Kauppi KL. Analysis Microbiological Analyses In: Roginski H, editor. Encyclopedia of Dairy Sciences. Amsterdam, Boston, London, New York: Academic Press and Elsevier Science; 2003;1:74-79.

12. Wehr HM, Frank JH. Standard Methods for the Examination of Dairy Products. 17th ed. American Public Health Association (APHA). Washington DC: Publications Marketing; 2004.

13. Patel DA, Siva CV, Sannabhadti SS. Sources of microbial contamination of raw milk. Ind J Dairy Sci. 1993;46:67-70.

14. Milk Processing Guide Series. FAO/TCP/KEN/6611 Project, Volume 2. 